\title{
Coronavirus Pandemic Impact on the Nexus Between Gold and Bitcoin Prices
}

\author{
Khaled L. AL-Naif ${ }^{1}$ \\ ${ }^{1}$ Amman University College, Al-Balqa Applied University, Jordan \\ Correspondence: Khaled L. AL-Naif, Amman University College, Al-Balqa Applied University, Jordan. E-mail: \\ kalneif@bau.edu.jo
}

Received: June 5, 2020

Accepted: July 21, 2020

Online Published: October 5, 2020

doi:10.5430/ijfr.v11n5p442

URL: https://doi.org/10.5430/ijfr.v11n5p442

\begin{abstract}
This study aims to explore the Coronavirus disease (COVID-19) effects on gold and bitcoin prices variabilities and on the relationship between each of them, both prices are denominated in USD.

The study period is divided into two groups, first group included 120 workdays before 30 January 2020 when WHO first declared COIVD-19 outbreak as a public health emergency of international concern, and the second group included 120 observations post that date. The period as a total extends from June. 24, 2019 to 22 of May 2020.

To this end, the study used the appropriate statistical tools including stationery and unit root test, Levene's test for the equality of variances, correlation, least squares regression, and pairwise Granger causality test.

The results of testing the equality of variances and homogeneity between each of the study groups before and after COVID 19 revealed a strong rejection of the null hypothesis of equal variances for gold but not bitcoin which was accepted. The results also indicate a significant relationship between gold and bitcoin before and after COVID-19, but the sign changed from negative to positive respectively.

Finally, the study concludes that there were significant effects of COIVD-19 on gold but not bitcoin prices. These results are consistent with gold's traditional role as a safe-haven in crises, and bitcoin as a 'virtual gold' which has some similarities, and likely to be complementary rather than in a competion with gold.
\end{abstract}

Keywords: gold, bitcoin, COVID-19, hedging

\section{Introduction}

Coronavirus disease (COVID-19) has plunged the world into a "crisis like no other". The IMF described the global downturn as the worst since the great depression of the 1930s and expected that the global economy will shrink by $3 \%$ this year.

In similar circumstances, the demand is increased for a 'safe-haven' asset, (which is defined as an asset that is negatively correlated or uncorrelated with other asset classes in times of market uncertainties or turbulence (Baur \& Lucey, 2010).

Traditionally, the gold characteristics such as its intrinsic value and low correlation with financial asset classes, especially in times of crisis or uncertainty, enabled it to be considered as a 'safe-haven' asset (Baur and McDermott (2010) and accepted globally as the most representative safe haven or hedge against volatility in another asset (Kyriazis, (2020).

Recently, Bitcoin (BTC) as a new asset class has been dubbed as 'virtual gold' and the gold for millennial (Burniske \& White, 2016), it gained more ground and value during the Greek and European sovereign debt crisis, (Bouri, 2017a; Luther and Salter, 2017), Surprisingly, its price exceeded the price of one ounce of gold in April 2017. Dyhrberg (2016) also argued that BTC has hedging abilities as gold.

In this sense, this study aims to explore the effects of COVID-19 on the price variance of BTC \& GD by testing the homogeneity between BTC before COVID-19 (BTC $\left.\mathrm{b}_{\mathrm{b}}\right)$ and after COVID-19 $\left(\mathrm{BTC}_{\mathrm{a}}\right)$ and also between gold price variance before COVID $\left(\mathrm{GD}_{\mathrm{b}}\right)$ and after it $\left(\mathrm{GD}_{\mathrm{a}}\right)$ and its effects on the relationship between them before and after COVID-19 by using the appropriate statistical tools. 
This is one of the first studies to explore this relationship and its results are expected to contribute to the hedging literature and to provide essential information that might be beneficial to investors as well as researchers. Our results are also useful for investment decision-making.

The remainder of this paper is organized as follows: Section 2 Literature Review and previous studies. Section 3 describes the methodology. Section 4 presents the results. Section 5 provides a discussion and the overall conclusion.

\section{Literature Review and Previous Studies}

\subsection{Corona Virus Disease (COVID-19)}

Coronavirus disease (COVID-19) is an infectious disease caused by a newly discovered coronavirus, SARS-CoV-2. World health organization WHO director-general declared that the outbreak constitutes a public health emergency of international concern (PHEIC) on 30 January 2020 and a pandemic on $11^{\text {th }}$ March 2020 (https://www.who.int/). The COVID-19 outbreak, which was first detected in China, had infected people in 219 countries. In $1^{\text {st }}$ June 2020, WHO statistics indicated that the confirmed cases were (5 939 234) case and the confirmed deaths were (367255).

COVID-19 dived the world into a "crisis like no other", affecting all sectors all over the world. The IMF described the global downturn as the worst since the great depression of the 1930s and expected that global economy to shrink by $3 \%$ this year (Jones, 2020) and predicts that the UK economy will shrink by $6.5 \%$ in 2020, and the US economy by 5.9\% this year, representing the biggest annual decline since 1946 (Ping, S. (2020). The Dow and the FTSE saw their biggest quarterly drops in the first three months of the year since 1987 (Jones, 2020). Investors fear that governments' actions may not be enough to stop such decline.

\subsection{Previous Studies}

Cryptocurrencies literature, in general, is scant, and till now there are no previous studies about COVID-19 effects on BTC and gold -up to the researcher knolwedge-.

Bouoiyour, et. al., (2019) sought to address whether BTC ever matched or even replaced gold as a safe haven. They reported a positive and strong correlation between BTC and gold returns coinciding with specific political and economic events. They indicated that gold and BTC benefits from the same economic conditions. They finally concluded that gold and BTC are likely to be complementary, rather than in competition with each other.

One of the most related previous studies is that of Al-Khazali, et. al., (2018), who examined the impact of positive against negative macroeconomic news surprises originating from large developed economies on the BTC and gold returns and volatility over the period July 19, 2010 - February 7, 2017. They found an asymmetric impacts and evidence that gold is different from BTC. Specifically, gold returns and volatility did systematically react to macroeconomic news surprises in a manner that were consistent with its traditional role as a safe-haven, whereas BTC prices and volatility did not react in a similar manner. In the same line, Li and Wang (2017) argued that BTC returns are affected by changes in economic fundamentals.

Regarding the hedging capability of BTC, while, Dyhrberg (2016) and Baur \& Lucey (2010) revealed that BTC and gold have similar hedging capabilities, Capie et al. (2005) suggested that BTC cannot be used as a hedge against exchange rates.

Regarding the relationship between gold and BTC, mixed results were reported by the previous empirical studies. While some of them found a positive relationship such as Patonov, (2020) and Bouoiyor, et. al., (2019), others such as; Kyriazis, (2020); Obryan (2019); and Su et.al,. (2020) pointed out that gold price is negatively related to that of BTC.

On the other hand, Kristoufek \& Scalas (2015) and Yermack (2013) denied the presences of any relationship between them. Finally, Gkillas \& Longin (2019) found a low extreme correlation between BTC and gold.

Through reviewing previous studies, it is clear that few studies have examined the relationship between gold and bitcoin in exceptional circumstances such as Corona, and thus this study is expected to contribute to stimulating more subsequent studies.

\section{Research Methodology}

\subsection{Methodology}

As WHO declared that the outbreak constitutes a public health emergency of international concern (PHEIC) on $30^{\text {th }}$ January 2020, our empirical study considered it as $\left(\mathrm{T}_{0}\right)$ and took an equal period before and after this date, the first period started from June. $24^{\text {th }}$, 2019 to $30^{\text {th }}$ January 2020 (yielding 120 observation) and the second period started 
from 31 January 2020 to 22 May 2020 (yielding 120 observation), consequently, logarithms were used throughout the analysis.

\subsection{Data}

In our study, we considered working days (daily) closing prices (expressed in US dollars). BTC price data were obtained from coinmarketcap.com and gold spot prices/OZ from gold.org.

\subsection{Study Variables}

BTC price (BTC): daily BTC closing price.

Gold price (GD): spot OZ Gold price.

The logarithms of daily prices expressed in US dollars for both variables were used.

\subsection{Hypotheses}

From the above discussion our preliminary hypotheses will be as follows:

H01: The variances of $\mathrm{BTC}_{\mathrm{b}} \& \mathrm{BTC}_{\mathrm{a}}$ are equal.

$\mathrm{H} 02$ : The variances of $\mathrm{GD}_{\mathrm{b}} \& \mathrm{GD}_{\mathrm{a}}$ are equal.

H03: There is no significant relationship between $\mathrm{BTC}_{\mathrm{b}}$ and $\mathrm{GD}_{\mathrm{b}}$.

H04: There is no significant relationship between $\mathrm{BTC}_{\mathrm{a}}$ and $\mathrm{GD}_{\mathrm{a}}$.

\subsection{The Model}

The linear model used in this study is given below:

$$
\begin{gathered}
\mathrm{BTC}_{\mathrm{i}}=\alpha+\beta^{*} \mathrm{GD}_{\mathrm{i}}+\mathrm{e} \\
\text { Model 1: } \mathrm{BTC}_{\mathrm{b}}=\alpha+\beta^{*} \mathrm{GD}_{\mathrm{b}}+\mathrm{e} \\
\text { Model 2: } \mathrm{BTC}_{a}=\alpha+\beta^{*} \mathrm{GD}_{a}+\mathrm{e}
\end{gathered}
$$

Where: $\alpha$ : the intercept, B: Coefficient, $\varepsilon$ : Error and $i=b$, a and All; $b$ and a indicate the period before and after COIVD 19 respectively, and (All) for the whole period.

\subsection{Statistical Methods}

To achieve the study objectives, the appropriate statistical tools were used, stationary and unit root tests, Levene's test for equality of variances, correlation, least squares regression, and pairwise Granger causality tests.

\section{Study Results}

\subsection{Descriptive Statistics}

Table I represents the descriptive statistics

Table 1. Descriptive statistics

\begin{tabular}{lcccc}
\hline & \multicolumn{2}{c}{$\mathrm{BTC}$} & \multicolumn{2}{c}{ Gold } \\
\hline Mean & $\mathrm{BTC}_{\mathrm{b}}$ & $\mathrm{BTC}_{\mathrm{a}}$ & $\mathrm{GD}_{\mathrm{b}}$ & $\mathrm{GD}_{\mathrm{a}}$ \\
Median & 3.978 & 3.902 & 3.168 & 3.204 \\
Maximum & 3.987 & 3.909 & 3.172 & 3.201 \\
Minimum & 4.114 & 4.014 & 3.189 & 3.243 \\
Range & 3.854 & 3.696 & 3.143 & 3.165 \\
Std. Dev. & 0.260 & 0.320 & 0.050 & 0.080 \\
Skewness & 0.065 & 0.072 & 0.012 & 0.022 \\
Kurtosis & -0.099 & -0.562 & -0.553 & -0.055 \\
Jarque-Bera & 2.095 & 2.880 & 2.207 & 1.915 \\
Probability & 4.287 & 6.397 & 9.269 & 5.943 \\
Observations & 0.117 & 0.041 & 0.010 & 0.051 \\
\hline
\end{tabular}

Source: Eviews calculations. 
Table 1 reported the descriptive statistics of the study variables, the results reported that the mean and median of $\mathrm{BTC}_{\mathrm{b}}$ are close to that of $\mathrm{BTC}_{\mathrm{a}}$, and also for that of GD.

The range however slightly increased from 0.26 to 0.32 and from 0.05 to 0.08 for BTC \& GD respectively. The standard deviations also increased from 0.06 to 0.07 and from 0.01 to 0.02 for BTC \& GD respectively.

These results indicate that prices fluctuations of BTC \& GD after COVID-19 pandemic were higher than before the crisis. The Jarque-Bera statistics however indicates that $\mathrm{BTC}_{\mathrm{a}}$ and $\mathrm{GD}_{\mathrm{b}}$ price series don't follow a normal distribution.

\subsection{Empirical Results}

In this section, Unit Root testing, correlation, independent samples, and simple regression tests are conducted.

\subsubsection{Stationary and Unit Root Testing}

The Augmented Dickey-Fuller test (ADF) and PP were used for testing the stationarity. The results are shown in Table 2 below:

Table 2. The results of ADF \& PP unit root tests

\begin{tabular}{|c|c|c|c|c|}
\hline & \multicolumn{2}{|c|}{ Level } & \multicolumn{2}{|c|}{$1^{\text {st }}$ deference } \\
\hline H0: & ADF (t. sta.) & $\begin{array}{ll}\text { PP } & \text { (t.sta.) }\end{array}$ & (t. sta.) & (t.sta.) \\
\hline $\mathrm{BTC}_{\mathrm{b}}$ & $-1.78 \quad(0.39)$ & $-1.39(0.58)$ & $-8.98 *(0.00)$ & $-11.74 *(0.00)$ \\
\hline BTCa & $-2.111(0.24$ & $-1.98(0.30)$ & $-12.78^{*}(0.00)$ & $-12.69 *(0.00)$ \\
\hline $\mathrm{GD}_{\mathrm{b}}$ & $-2.089(0.25)$ & $-1.95(0.31)$ & $-12.34 *(0.00)$ & $-12.49 *(0.00)$ \\
\hline $\mathrm{GD}_{\mathrm{a}}$ & $-1.313(0.62)$ & $-1.64(0.46)$ & $-5.73 *(0.00)$ & $-11.428 *(0.00)$ \\
\hline & \multicolumn{2}{|c|}{0.01 level } & \multicolumn{2}{|c|}{-3.4870} \\
\hline $\begin{array}{l}\text { I est } \\
\text { critical }\end{array}$ & \multicolumn{2}{|c|}{0.05 level } & \multicolumn{2}{|c|}{$2.8863-$} \\
\hline values: & \multicolumn{2}{|c|}{0.10 level } & \multicolumn{2}{|c|}{-2.5800} \\
\hline
\end{tabular}

* reject null hypotheses at less than or equal 0.05 significant levels.

Source: Eviews calculations.

The reported results in Table 2 clearly demonstrate that the null hypothesis of each of the time series has a unit root that cannot be rejected for the levels since their ADF \& PP values are less than critical values at the (5\%) level of significance. Therefore, all of the variables are non-stationary in their levels. However, the results indicate that the null hypothesis is rejected for the $1^{\text {st }}$ differences; all variables are stationary in their $1^{\text {st }}$ differences.

Therefore, we conclude that all of the variables under investigation are individually integrated into order one I (1). 4.2.2 Correlation Results

Table 3 reports the correlation matrix between study variables.

Table 3. Correlation matrix

\begin{tabular}{lllllr}
\hline & $\mathrm{BTC}_{\mathrm{b}}$ & $\mathrm{BTC}_{\mathrm{a}}$ & $\mathrm{GD}_{\mathrm{b}}$ & $\mathrm{GD}_{\mathrm{a}}$ \\
\hline $\mathrm{BTC}_{\mathrm{b}}$ & 1 & & & \\
$\mathrm{BTC}_{\mathrm{a}}$ & 0.1191 & 1 & & \\
$\mathrm{GD}_{\mathrm{b}}$ & $-0.2678^{* * *}$ & $0.2216^{* *}$ & 1 & \\
$\mathrm{GD}_{\mathrm{a}}$ & $-0.638^{* * *}$ & $0.3172^{* * *}$ & $0.4376^{* * *}$ & 1 \\
\hline
\end{tabular}

$* * * \operatorname{Sig}<1 \%, * * 5 \%, * 10 \%$

Source: Author's calculations 
Table 3 shows that the significant negative correlation $(-0.27)$ between $\mathrm{BTC}_{\mathrm{b}}$ and $\mathrm{GD}_{\mathrm{b}}$ had transformed into a significant positive correlation (0.32) between $\mathrm{BTC}_{\mathrm{a}}$ and $\mathrm{GD}_{\mathrm{a}}$ after COIVD 19.

Additionally, while there was a significant positive correlation (0.43) between $\mathrm{GD}_{\mathrm{b}}$ and $\mathrm{GD}_{\mathrm{a}}$, the results indicate an absence of a significant correlation between $\mathrm{BTC}_{\mathrm{a}}$ and $\mathrm{BTC}_{\mathrm{b}}$.

\subsubsection{Homogeneity of Variance Test}

To test the equality of variance, Levene's test represented in Table 4.

Table 4. Levene's test for equality of variances (SPSS)

\begin{tabular}{crrr}
\hline $\mathrm{H} 0:$ & $\begin{array}{c}\text { Levene } \\
\text { Statistic }\end{array}$ & Sig & Results \\
\hline The variances of $\mathrm{BTC}_{\mathrm{b}} \& \mathrm{BTC}_{\mathrm{a}}$ are equal. & 2.219 & 0.138 & Accept H0 \\
The variances of $\mathrm{GD}_{\mathrm{b}} \& \mathrm{GD}_{\mathrm{a}}$ are equal. & 53.09 & 0.000 & Reject H0 \\
\hline
\end{tabular}

Source: SPSS calculation.

Table 4 results fails to reject the null hypothesis of equal variances for BTC at the 0.05 significance level since the value of the Levene's test statistic is 2.219 . Thus, we conclude that there is ahomogeneity of BTC price variance before and after COVID 19 with insufficient evidence to claim that the variances are not equal.

On the other hand, the results showed that Levene's statistic for gold (53.091) is significant whereas the probability is 0.00 . So, we rejected the null hypothesis of equal variances for gold and we conclude that there is a heterogeneity of gold price variance before and after COVID 19 with a sufficient evidence to claim that COVID has affect the gold price variances.

4.2.4 Least Squares Regression Analysis Results

Table 5 represents the third and fourth hypotheses testing results.

Table 5. Regression analysis results

\begin{tabular}{|c|c|c|c|c|}
\hline \multirow[t]{2}{*}{$\begin{array}{l}\text { Method: } \\
\text { Least } \\
\text { Squares }\end{array}$} & \multicolumn{2}{|c|}{ Model 1: } & \multicolumn{2}{|c|}{$\mathrm{BTC}_{\mathrm{a}}(-1)$} \\
\hline & Coefficients & $\mathrm{T}$ & Coefficients & $\mathrm{T}$ \\
\hline $\mathrm{C}$ & 8.583 & $5.77 * * *$ & 0.669 & 0.7311 \\
\hline $\begin{array}{l}\mathrm{GD}_{\mathrm{b}} \\
(-1)\end{array}$ & -1.453 & $-3.1 * * *$ & & \\
\hline $\begin{array}{l}\text { GDa } \\
(-1)\end{array}$ & & & 1.009 & $3.53 * * *$ \\
\hline $\mathrm{R}^{2}$ & & & & \\
\hline F-Stat & 11. & & & \\
\hline
\end{tabular}

*** Sig, at $1 \%$ level.

Source: Eviews calculation.

As shown in Table 5, the results of model 1 reports that, as $\mathrm{GD}_{\mathrm{b}}(-1)$ coefficient in the previous period of Covid-19 is negative (-1.453) and statistically significant at $\alpha<0,01$, we reject the null hypothesis H03: There is no significant relationship between $\mathrm{BTC}_{\mathrm{b}}$ and $\mathrm{GD}_{\mathrm{b}}$, and accept Ha: There is a significant relationship between $\mathrm{BTC}_{\mathrm{b}}$ and $\mathrm{GD}_{\mathrm{b}}$ (before COVID-19). The estimation of the regression model as follows:

$$
\mathrm{BTC}_{\mathrm{b}}(-1)=8.583-1.453 * \mathrm{GD}_{\mathrm{b}}(-1)
$$


In addition, model 2 results showed that the (-1) coefficient in the following period of Covid-19 did transformed into being significantly positive (1.009) at $\alpha<0,01$, this indicates that the crises did had a significant effect on BTC and GD relationship. Thus, we reject the null hypothesis H04: There is no significant relationship between $\mathrm{BTC}_{\mathrm{a}}$ and $\mathrm{GD}_{\mathrm{a}}$ and accept Ha: There is a significant relationship between $\mathrm{BTC}_{\mathrm{a}}$ and $\mathrm{GD}_{\mathrm{a}}$.

The estimation of the regression model as follows:

$\mathrm{BTC}_{\mathrm{a}}(-1)=0.669+1.009 * \mathrm{GD}_{\mathrm{a}}(-1)$

The R-squared (F- statistics) for model1 and model 2 are 0.09 (11.12) and 0.10 (13.03) respectively.

4.2.5 Granger Causality Test

Table 6 represents the results of the pairwise Granger causality test.

Table 6. Results of the pairwise Granger Causality Test

\begin{tabular}{|c|c|c|c|c|}
\hline Causality direction & Lag & F-Statistic & Probability) & Result \\
\hline BTC $_{b}$ does not Granger Cause BTC & 2 & 0.074 & $(0.93)$ & \multirow{8}{*}{$\begin{array}{l}\text { Accept } \\
\text { H0 }\end{array}$} \\
\hline $\mathrm{BTC}_{\mathrm{a}}$ does not Granger Cause $\mathrm{BTC}_{\mathrm{b}}$ & 2 & 1.18 & $(0.84)$ & \\
\hline $\mathrm{GD}_{\mathrm{b}}$ does not Granger Cause $\mathrm{GD}_{\mathrm{a}}$ & 2 & 0.24 & $(0.79)$ & \\
\hline$G_{a}$ does not Granger Cause $G_{b}$ & 2 & 0.04 & $(0.96)$ & \\
\hline $\mathrm{GD}_{\mathrm{b}}$ does not Granger Cause $\mathrm{BTC}_{\mathrm{b}}$ & 2 & 0.37 & $(0.69)$ & \\
\hline $\mathrm{BTC}_{\mathrm{b}}$ does not Granger Cause $\mathrm{GD}_{\mathrm{b}}$ & 2 & 0.39 & $(0.68)$ & \\
\hline $\mathrm{GD}_{\mathrm{a}}$ does not Granger Cause $\mathrm{BTC}_{\mathrm{a}}$ & 2 & 1.18 & $(0.31)$ & \\
\hline $\mathrm{BTC}_{\mathrm{a}}$ does not Granger Cause $\mathrm{GD}_{\mathrm{a}}$ & 2 & 0.22 & $(0.81)$ & \\
\hline
\end{tabular}

Source: Eviews calculation.

Note: for F-statistics, probabilities are greater than 0.01 levels or $5 \%$ level null hypotheses are rejected at that level.

Table 6 shows that all $\mathrm{F}$ tests are insignificant at the 0.05 level of significance. These results imply that we can't reject all of the null hypotheses, and thus we conclude the absence of a short-term causality relationship between all of the study variables.

\section{Discussion and Conclusion}

Although there are a number of determinants, especially time, the results of this study provides benefit to investors and researchers and will hopefully motivate researchers to address the economic and financial implications of the exceptional crisis of Corona.

The results of correlation and regression tests revealed a negative and weak correlation between $\mathrm{BTC}_{\mathrm{B}}$ and $\mathrm{GD}_{\mathrm{B}}$, which implies its benefit of hedging and diversification, These results are in line with several previous studies such as that of Kyriazis, (2020); Obryan (2019); and Su et.al,. (2020) who pointed out that, gold is negatively related to the price of BTC.

The results of correlation and regression analysis before and after COVID 19 were different, and the relationship between the study variables has transformed from positive to negative respectively.

These results are in line with Patonov, (2020) and Bouoiyour, et. al., (2019) and with Dyhrberg (2015), and inconsistent with Kristoufek and Scalas (2015) and Yermack (2013).

The result of testing the equality of variances strongly rejects the null hypothesis of equal variances for gold while accepting it for BTC.

These results are in line with Al-Khazali, et. al., (2018) who reported that gold is different from BTC, and with the gold traditional role as a safe-haven, whereas BTC prices and volatility do not mostly react in a similar manner.

The results contradicted that of Li and Wang (2017), who argued that BTC returns are affected by the changes in economic fundamentals. The results also contradicted Dyhrberg (2016) and Baur and Lucey (2010) who revealed that BTC and gold have similar hedging capabilities. 
Finally, the study concludes that the COVID-19 impacts were stronger for gold than for BTC. These results are consistent with gold's traditional role as a safe-haven in turmoil and confirmed BTC as a new asset class that has been dubbed as 'virtual gold' which has some similarities, and likely to be complementary rather than in competition with gold.

\section{References}

Al-Khazali, O., Elie, B., \& Roubaud, D. (2018). 'The impact of positive and negative macroeconomic news surprises: Gold versus Bitcoin. Economics Bulletin, 38(2), 373-382.

Baur, D., \& Lucey, B. (2010). Is Gold a Hedge or a Safe Haven? An Analysis of Stocks, Bonds and Gold. Financial Review. 45(2), 217-229. https://doi.org/10.1111/j.1540-6288.2010.00244.x

Baur, D., \& McDermott, T. (2010). Is gold a safe haven? International evidence. Journal of Banking \& Finance, 34(8), 1886-1898. https://doi.org/10.1016/j.jbankfin.2009.12.008

Bouoiyour, J., Selmi, R., \& Wohar, M. (2019). Bitcoin: competitor or complement to gold?. Economics Bulletin, 39(1), 186-191.

Burniske, C., \& White, A. (2016). Bitcoin: Ringing the bell for a new asset class. (White paper) Ark invest research. Retrieved from https://research.arkinvest

Capie, F., Mills, T. C., \& Wood, G. (2005). Gold as a Hedge against the dollar. J. Int. Financ. Mark., Inst. Money, 15, 343-352.

Dickey, D. A., \& Fuller, W. A. (1981). Likelihood ratio statistics for autoregressive time series with a unit root. Econometrica, 49(4), 1057-1072. https://doi.org/10.2307/1912517

Dyhrberg, A. (2016). Hedging capabilities of bitcoin. Is it the virtual gold?. Finance Research Letters, 16, 139-144. https://doi.org/10.1016/j.frl.2015.10.025

Dyhrberg, A. H. (2015). Hedging capabilities of bitcoin is it the virtual gold?, UCD Centre for Economic Research. Working Paper Series, No. WP15/21, University College Dublin, UCD School of Economics, Dublin.

Gkillas, K., \& Longin, F. (2019). Is Bitcoin the New Digital Gold? Evidence From Extreme Price Movements in Financial Markets, January 18. https://doi.org/10.2139/ssrn.3245571

Jones, L., Palumbo, D., \& Brown, D. (2020). Coronavirus: A visual guide to the economic impact. Retrieved from https://www.bbc.com/news/business-51706225

Kristoufek, L. (2015). What are the main drivers of the Bitcoin price? Evidence from wavelet coherence analysis. PloS one, 10(4), e0123923.

Kyriazis, N. (2020). Is Bitcoin Similar to Gold? An Integrated Overview of Empirical Findings Journal of Risk Financial Management, 13, 88. https://doi.org/10.3390/jrfm13050088

Li, X., \& Wang, C. A. (2017). The technology and economic determinants of cryptocurrency exchange rates: The case of Bitcoin. Decision Support Systems, 95, 49-60.

Luther, W. J., \& Salter, A. W. (2017). Bitcoin and the Bailout. The Quarterly Review of Economics and Finance. https://doi.org/10.1016/j.qref.2017.01.009

Obryan, P. (2019). Exploring the dynamics of Bitcoin's price: A bayesian structural time series approach. Eurasian Economic Review, 9(1), 29-60.

Patonov, N. (2020). Gold price and bitcoin exchange rate: is there a correlation?. Entrepreneurship, VIII(1), 119-124.

Ping, S. (2020). Coronavirus: 'World faces worst recession since Great Depression'. BBC News, 14 April 2020. Retrieved from https://www.bbc.com/news/business-52273988

Retrieved from https://www.gold.org/goldhub/data/gold-prices/>

Retrieved from https://coinmarketcap.com/currencies/bitcoin/historical- data/?start=20130429\&end=20200529

Retrieved from https://www.itl.nist.gov/div898/handbook/eda/section3/eda35a.htm

Retrieved from https://www.who.int/emergencies/diseases/novel-coronavirus-2019

Retrieved from https://www.who.int/news-room/articles-detail/standardization-of-vaccines-for-coronavirus-disease-COVID-19 
Robertson, B. H. (2018). Bitcoin: The New Virtual Gold? An investigation into the diversification properties of Bitcoin within a South African portfolio. Master of Commerce specialising in Finance in the field of Investment Management, University of Cape Town.

Su, C., Qin, M., Tao, R., \& Zhang, X. (2020). Is the status of gold threatened by Bitcoin?, Economic Research-Ekonomska Istraživanja, 33(1), 420-437. https://doi.org/10.1080/1331677X.2020.1718524

World Gold Council. (2020). Investment Update COVID-19: potential impact on the global economy and gold $\begin{array}{lccr}\text { performance } & 14 & \text { May, } & 2020 . \\ \text { https://www.gold.org/goldhub/research/covid-the-economy-and-gold }\end{array}$

Yermack, D. (2013). Is Bitcoin a Real Currency?. SSRN Electronic Journal. https://doi.org/10.2139/ssrn.2361599

\section{Copyrights}

Copyright for this article is retained by the author(s), with first publication rights granted to the journal.

This is an open-access article distributed under the terms and conditions of the Creative Commons Attribution license (http://creativecommons.org/licenses/by/4.0/). 